\title{
Clergy, Nobility and Crown in Decadência
}

Yi LIU ${ }^{1}$

RESUMO: No presente trabalho tenciono indagar as causas internas que dirigiram o império marítimo português à decadência. Depois de uma revisitação da historiografia relativa ao declínio do Estado da Índia, procedo a uma análise do triângulo de Monarca-Igreja-Nobreza durante os Descobrimentos e dos seus papéis respectivos no evoluir do Império português. É verificável que a absolutização da Coroa, a sobre-expansão do clero e a potenciação da aristocracia tornaram-se as características mais salientes e duradouras na estrutura social portuguesa depois de o país se lançar nas façanhas marítimas, do que resultou a agricultura prejudicada e indústria atrasada. A predominância dessas três instituições, por um lado, impediu a ascensão da burguesia, assim dificultando a transformação da economia mercantilista na capitalista, e, por outro, promoveu espírito aventureiro não-produtivo e aversão contra o trabalho manual tanto na metrópole como no ultramar. Portanto, o declínio do Império português principia-se "de dentro" ao invés de "de fora", e bem antes de ataques holandeses que só o aceleraram.

PALAVRAS-CHAVE: Império Português; historiografia; mercantilismo.

Decadência is of course an old theme in Portuguese historiography, and historians are quite unanimous in relation to 
the milestone in the Portuguese decline: losses of Moluccas, Hormuz, M elaka and Ceylon in the early $17^{\text {th }}$ century signaled the knell of the Estado da Índia, and the following conquest of Cochin by the VOC (Dutch East India Company) in 1663 constitutes the closing chapter of Decadência of Portuguese Asian empire. However, regarding the reasons or factors that led to the decline, historians are far from being united. Some historians like V. A. Smith, W. W. Hunter attributed the decline to the corrupt nature of Portuguese administration in Asia and to the moral decay of the officeholders - similar reasons were given by $M$ arcus Cicero to explain the collapse of the Roman Republic. Other historians, say C. R. Boxer and Niels Steensgaard, argued that it was not Portuguese corruption but Dutch superiority that turned the table in Asia during the first half of the $17^{\text {th }}$ century, and

the entrance of the more advanced proto-capitalist entrepreneurial companies of the English and Dutch into the Asian trade doomed the monarchical monopolism of the Portuguese Crown to virtual extinction. ${ }^{2}$

Besides, the Portuguese historian, Oliveira Martins, stressed the idea of organism, considering that the decline is the corollary of the rise and, thus, inevitable.

Although the moral corruption in the Estado da Índia could be evidenced in a number of itinerários, cartas, relações and books written by persons with first-hand experiences in that period, it is superficial and vague to impute the decline onto a moral ground, given that the decay of morality is the result rather than the reason of a series of problems, such as flawed administration, incompetent supervision or out-dated mentality. Admittedly, in a sense or another, the Dutch joint-stock company is more 
advanced in organizational form, but they had their own defects as well. And it is still questionable if the joint-stock companies were necessarily better than what they replaced. ${ }^{3}$ Changes and evolutions are the consequences of both external and internal motivations, and external ones, more often than not, effect through internal ones. What if the Viceroy of the Estado da Índia had had more than a pinch of soldiers at hand? What if a regular army had stationed in Portuguese Asia? There can be countless such "what if", but the point is that it's ex parte to over-appreciate the superiority of the Dutch without attending to the self-weakening causes inside the Portuguese empire. Although in the course of History, no trans-continental empires (M acedonia, Roman Empire, Empire of Mongol and more recently Great Britain) escaped from the fate of decline or even of disappearance, it is little convincing to use fatalist theory of organism suggested by Oliveira Martins to explain Decadência, as it is ridiculous to use "every man dies" to explain "why man dies". Simply speaking, man dies because one or some organs degenerate and fail to function; so will do an empire when one or some of its organs deteriorate. The clergy and the nobility under the influence of the absolutist Crown, in my view, could be considered as two malfunctioning organs in the Portuguese imperial body, both in metropolis and in the Estado da Índia which, in many respects, was a microcosm of the metropolis. Hereinafter, I'll examine their roles and how they acted interrelatedly in eroding the Portuguese imperium.

In his famous speech - Causas da Decadência dos Povos Peninsulares nos Últimos Três Séculos, Antero de Quental stated that the first cause led to the decadence of both Portugal and Spain is the transformation of Catholicism by the Concilium of Trent, which gave birth to the notorious Inquisition. 
Com a Inquisição, um terror invisível paira sobre a sociedade: a hipocrisia torna-se um vício nacional e necessário: a delação é uma virtude religiosa: a expulsão dos Judeus e M oiros empobrece as duas nações, paralisa o comércio e a indústria [...] a perseguição dos cristãos-novos faz desaparecer os capitais. ${ }^{4}$

One of the consequences of the Inquisition was the expulsion of New Christians and Moors who, to a great extent, contributed to the prosperity of Portugal's economy. "Laboriosos e flexíveis, os Judeus primavam nos ofícios manuais, nos tratos mercantis, nas agências lucrativas; e os mouros, por seu lado, salientavam-se nas profissões, liberais e no granjeio das propriedades" ${ }^{5}$, writes António Sérgio. The banishment of these peoples caused, on one hand, the atrophy and evacuation of certain industries (D. Luís da Cunha once commented that: "vem a ser que a Inquisição, prendendo uns por crime de judaísmo, e fazendo fugir outros para fora do reino... [F]oi preciso que as tais manufacturas caíssem, porque os chamados cristãos-novos as sustentavam."), thus leaving a huge gap to be filled by foreigners (bankers, agents, artisans) who would enrich their own nations by sipping Portuguese wealth, and, on the other, the expelled Jews and Moors propelled the development of other European nations at the expense of brain - and money drain in Portugal. "Tiranizados em Portugal, foram os judeus fomentar os progressos económicos da Holanda e da Inglaterra, sendo incalculável o que perdemos com essa obra de perseguição." ${ }^{6}$ And

this continual emigration of 'New Christian' commercial and financial talent from the reign of King John III to that of King John $\mathrm{V}$ was advantageous for the prosperity of Amsterdam, London, Rouen and Leghorn, but obviously disadvantageous for 
the Portuguese economy, ${ }^{7}$

adds Boxer. Compared with its Castilian counterpart, Portuguese Inquisition might be more damaging, given its small-sized and highly unified territory. Furthermore, because the Portuguese Crown did not need to suppress Lutheranism or to fight against Protestants, it could dedicate itself to purge those new Christians more wholeheartedly than its neighbor.

Besides,

- Santo Ofício serviu de arma anti-capitalista por parte da ordem nobiliárquico-eclesiástica, ou nas lutas entre grupos de interesses rivais [...]. Tal discriminação agiu como freio poderoso no sentido de travar a formação de uma burguesia economicamente inovadora e defender uma nobreza profundamente mercantilizada dos assaltos da concorrência. ${ }^{8}$

Obviously, the rampant inquisitional activities were partly due to a fragile middle class without enough ideological and economic independence that could react to the Inquisition. Although somewhat simplistic, Vianna Moog was not completely wrong in asserting that

um católico, como capitalista, será sempre um capitalista canhestro. Em ambos os casos estaremos em presença de um cisma da alma, este cisma que, além de dar lugar ao triunfo do capitalismo dos povos protestantes, será o grande responsável pela decadência dos povos peninsulares. Paradoxalmente [...] esta decadência vai começar no momento exato em que portugueses e espanhóis põem a mão nas mais fabulosas fortunas que 0 O cidente jamais conhecera. ${ }^{9}$ 
Another consequence related to the post-Trent Catholicism is the Jesuitism that both Oliveira M artins and Quental considered as a factor of Portuguese decline. However, while it is true that during hundreds of years of overseas expansion, Portuguese lost their scientific pioneership and experimentalist spirit developed at the beginning of os Descobrimentos when Portuguese boasted that in one day they could know more than ancient Romans and Greeks did in 100 years, it seems unjust to attribute Reino Cadaveroso (António Sérgio) or Reino da Estupidez (Francisco de Mello Franco) to Jesuit education which had a wide range of impacts both on Portugal and on her colonies.

The Inquisition also took broader effects in political domain. It served as one of the Crown's tools to expand the royal power and to control more tightly its kingdom and subjects, especially the povo (plebeian).

A Inquisição e o fanatismo inquisitorial eram apenas um dos aspectos da perversão do espírito religioso e da subordinação da I greja ao absolutismo do Estado. Sob os efeitos dissolventes do ouro, o Estado, a nobreza e o alto-clero haviam-se dado as mãos para impor a lei despótica dos seus interesses. ${ }^{10}$

\section{Consequently,}

in the process, the Catholic orthodoxy of Portugal was reinforced, the social and economic dominance of the aristocracy solidified, and the prospects for the development of a prosperous and independent middle class in Portugal greatly retarded. Persecution of the cristãos-novos reduced Portuguese economic resources at a time when the country was facing increased 
difficulty meeting the military and economic challenges of empire. ${ }^{11}$

Although Diogo do Couto observed that the Portuguese King was always a keen Catholicism promoter, and the Inquisition did give the Crown greater mastery over the hierarchy of the church, religious orders were not always under effective control of the King, and it was not rare that these orders caused subversive effects on the Crown's strategic plans, thus, putting the whole empire at risk. Plus, the Church was always ready to counter-strike any innovative reform that might affect its interests, even those carried out by the Crown. This is especially true when Regent Pedro planned to reform the Estado da Índia. The Archbishop, the Inquisitor-General and their minions all tried hard to frustrate the Regent's reform initiatives by exerting their huge and longstanding influence in the Portuguese overseas territories (as an idiom says "Vice-rei vá, vice rei vem, Padre Paulista sempre tem"). One of the contributions that religious orders made to undermine the empire is the manpower drain, turning even more severe the problem of lack of soldiery in the Estado da Índia. "Once a soldier arrived in India, one of the easiest and quickest methods to evade service was to join a religious order." ${ }^{\prime 2}$ The Count of Linhares, Viceroy of the Estado da India in the 1630s, also reported to the Crown that religious orders snatched away at least half of the soldiery sent from Portugal, "thus depriving the armadas and fortalezas of badly needed manpower at a time when the Estado da Índia confronted a host of enemies."13 About thirty years later, another Viceroy, Mello de Castro, testified that "one does not find in Goa and its environs more than 320 or so permanent Portuguese residents, while the priests exceed $700^{\prime \prime}$ As we all know, the lack of 
manpower is a recurring theme in Portuguese Asia. The constant leakage of soldiers from military service to religious orders undoubtedly made the Estado da Índia weaker and more vulnerable to foreign attacks. So, whether or not the VOC was superior, Portuguese had al ready made the Dutch work easier.

The practice of Religiosos not only stole the Crown of necessary manpower to defend the empire but also robbed a source of income both inside and outside Portugal. Glenn Ames writes that the Church

owned between one fourth and onethird of the land in the kingdom, held rights to the décima de Deus or a tenth share of the royal revenues, and also received a plethora of other donations through mortmain and other devices from 'pious believers'. The Inquisition itself constituted yet another bastion of clerical influence and power within the kingdom. ${ }^{15}$

Therefore, the Church was a de facto "a state within state," absorbing all kinds of resources but yielding little productivity and positive effects on safeguarding the overseas empire. At the same time, from the 15th to the 18th century the quantity of men of the cloth increased in an extraordinary way, and so did the number of convents and monasteries, which exerted enormous pressure on both Royal and Viceroy's treasury. M ore formidable was the social and economic impact derived from the network of Religiosos omnipresent in the Portuguese society, from the great portion that the Church withdrew from renda nacional and from the vast fallow land owned by the Church/clergy. Godinho suggested that during the closing years of the 16th century and a long period in the $17^{\text {th }}$ century, the percentage of clergymen in combination with nobles and traders soared to no less than 
36.8\%; and if added their dependents and the otiose people, the non-productive population occupies $40.5 \%$ of the whole nation. Moreover, the population dedicated to agriculture was only around $1 / 3$ of the whole. In a pre-modern society in which the land cultivation mainly depended upon manpower, the amount of workforce in agriculture was vital to the foodstuff output. With so much reduced primary sector, industry and tertiary sector would only envisage a dim prospect for development.

In fact, the royal absolutism alone is not necessarily the trigger of the decadence, given that during the reign of the Regent Pedro, one of the most absolutist rulers of Portugal, Portugal achieved a series of political and economic successes both in Asia and in Europe alike. ${ }^{16}$ What substantially sabotaged the Portuguese empire was the swelling and inefficient nobility under the patronage of the Crown. Perry Anderson, in Lineages of the Absolutist State, argues that

absolutism represented at base a redeployed form of feudalism designed to protect a threatened aristocracy from the twin threats of a rising bourgeoisie and a peasantry freed from the most onerous burdens of feudalism. For M arx and Engels, this period not surprisingly embodied a transitional one from feudalism to capitalism when the power of the 'warring classes' of noble and bourgeois was so nearly equal that 'State power, as the ostensible mediator' acquired for the moment 'a certain degree of independence of both. ${ }^{17}$

However, in Portugal, the alliance between the Crown and the aristocracy greatly hampered the rise of bourgeoisie, and the should-be "threatened aristocracy" remained predominant over bourgeoisie and peasantry as long as the Crown possessed 
absolutist power.

In the period before os Descobrimentos, the Portuguese Crown was relatively liberal. From D. Afonso II (1211) onward, the Cortes had been convoked where allegedly every social class could voice its opinions and, accordingly, the royalty was limited and the local political power was secured and developed so that a quasi-liberal spirit was instilled. In 1385, the Cortes even proposed that

rei formaria o seu Conselho de cidadãos das principais cidades do reino, escolhidos sobre propostas de listas tríplices; - que ouviria os povos em todos os negócios que lhes tocassem; - que se thes não imporiam tributos, sem serem ouvidos e sem que com sua decisão e consel ho se buscassem os meios suaves para a sua execução; - que não faria a guerra, nem a paz, sem seu consentimento. ${ }^{18}$

But along with os Descobrimentos, the Crown saw its treasury replete of profits gained from the monopoly in spice trade and other fruitful business in Carreira da Índia, which enabled the Crown to dispense frequent meetings with the Cortes whose approval was necessary for the Crown to increase budgets. The Table 1 illustrated statistically how Portuguese Cortes declined during the period of os Descobrimentos. 
TABLE 1 - Frequency of the Portuguese Cortes, 1383-1557

\begin{tabular}{lcc}
\hline Ruler & Years reigned & Cortes summoned \\
\hline João I (1383-1433) & 50 & 25 \\
Duarte (1433-1438) & 5 & 4 \\
Afonso V (1438-1481) & 43 & 22 \\
Joâo II (1481-1495) & 14 & 4 \\
Manuel I (1495-1521) & 26 & 4 \\
João III (1521-1557) & 36 & 3 \\
\hline
\end{tabular}

Source: Serrão, Joel (ed.) Dicionâario de histâoria de Portugal, Iniciativas Editoriais, [1965-1971], 3:153.

If the splendid undertaking of os Descobrimentos was mainly engineered by the Crown and carried out by the adventurous nobility, the decadence of Portuguese administrative system in overseas territories was also due to their presence. In the era of expansion, a highly centralized government represented by a strong Crown could implement enterprises in a resolute way, which helped to overcome obstructions and oppositions. Nevertheless, in the post-expansion period, the absolute power of the Crown would retard the formation of an efficient, local-condition-suiting administrative system in its colonies, leaving them often improperly managed.

European monarchs have always been far more interested in what went on under their noses than in places thousands of miles away, and the only historic empires safe from periodic neglect were 
those built and operated by joint stock companies, which had no outside interests to distract them [... ] but the weakest point in them was precisely at the center. Once the rulers themselves became immersed in interests close at hand, their empires only came to notice whenever money was sent home which could be disbursed to keep the royal credit intact. ${ }^{19}$

The Crown's absolutism was also represented in geographic and demographic terms: the whole country's wealth, human resources and all kinds of activities concentrated in Lisbon which was a like bloodsucker that swelled itself by depleting the rest of the country's energy and resources. The consequences were calamitous. Before and at the beginning of os Descobrimentos, Portugal, as one of the nations in Europe that most exported agricultural products (cereal salted fish and dried fruits), boasted a relatively strong agriculture. But, from the reign of $D$. M anuel I onward, Portugal could not self-sustain in foodstuff any more and began to import wheat from Italy and cereal from Netherlands.

The domestic economy, however, entered a phase of relative stagnation. Certain domestic export products, such as wine, olive oil, and fruit, maintained their volume, but cultivation of the key staple, wheat, declined as land was taken out of use. This was due to partial depopulation in some rural areas in central Portugal, as a combination of low wages, seigniorial oppression, and the lure of an easier life drew peasants to the larger cities or the empire. The food problem was made worse by intermittent bad harvests and several severe plagues during the reign, requiring food imports that weighed heavily on the exchange balance. The population of Portugal, which had expanded to possibly as many 
as 1,400,000 early in the century, ceased to increase and for the rest of the century was in danger of declining. ${ }^{20}$

Abandoning fields and lands, the rural population converged into big cities, especially into Lisbon, dreaming of making easy money and living a noble life. Because of the decline of agriculture (foodstuff was not enough to sustain extra population. And because the peasants, in general, lived in misery and poverty, many of them didn't marry, which resulted in very low natality), of the constant emigration, and of the high death rate in Indiamen and in other parts of Portuguese overseas territories where sanitary conditions were abominable, Portugal's population decreased from nearly 3 million in the epoch of $D$. João II to little more than 1 million in 1640. Without abundance of labor force and enough agricultural production, which means the unavailability of cheap raw material, the labor-intensive industries and factories could not be developed (another possible factor that led to the backwardness of Portuguese industry was that with the influx of huge quantity of precious metals, prices of labor and raw material skyrocketed so that it became less profitable to set up factories in Portugal than in other parts of Europe. ${ }^{21}$ ). Consequently, the nobility and the Church fully took advantage of the exodus of peasants from rural areas to expand their fiefdoms where normally the agricultural productivity was very low. In the 17th century, according to Godinho, about $95 \%$ of the peninsular land belonged to the nobility and clergy.

While the whole country was in wane,

by contrast, Lisbon grew enormously. The royal monopoly system concentrated trade disproportionately in Lisbon, leading to hypertrophy of the chief port and the decline of most of the 
small coastal cities. By 1550, Lisbon had reached a population of 100,000 , making it the largest city in the peninsula. ('By the end of the $16^{\text {th }}$ century, the total population of Portugal was about 1.4 million, with 120,000 people living in Lisbon. The next largest city was Oporto with not more than 14,000 inhabitants. ${ }^{22}$ ) By 1620, Lisbon had grown to approximately 165,000 [... ] Lisbon more and more became a parasite on the Portuguese economy and empire, for rather than being a center for new enterprise, it was increasingly a center for consumption of profits. ${ }^{23}$

Due to such tight economic centralization, the bourgeoisie that badly lacked independence and resources, declined rapidly. And, the internal colonization initiated from the $15^{\text {th }}$ century also ceased to progress and even showed evidence of retrogradation. The Portuguese countryside remained hopelessly in medieval times.

Um Estado rico numa nação pobre, onde a riqueza vinda de fora quebrava a coluna vertebral do trabalho interno e provocava o crescimento de uma falsa classe média que nada fazia e que, como uma corcunda enorme, ia crescendo à custa do resto do corpo do País e atrofiando com o seu peso as classes produtivas que já quase se limita aos camponeses. ${ }^{24}$

Saraiva summarized.

The Portuguese Crown's absolutism was also manifested in the multiplication and prosperity of noblemen, who heavily relied on the King's patronage. "As nossas monarquias, porém, tiveram um carácter exclusivamente aristocrático: eram-no pelo princípio, e eram-no pelos resultados. Governava-se então pela nobreza e para a nobreza." 25 The sustained Conquistas were, to a 
great extent, propelled by the nobility which was adventurous in nature, militarily oriented and title-zealous ${ }^{26}$.

TABLE 2 - Number of Nobles in the Royal Household, Afonso V to João III

\begin{tabular}{lc}
\hline Afonso V & 1.092 \\
João II & 264 \\
Manuel I & 894 \\
João III & 2.493 \\
\hline
\end{tabular}

Source: Serrão, Joel (ed.) Dicionâario de histâoria de Portugal, Iniciativas Editoriais, [1965-1971], 3:153.

The consequence of aristocratization of Portugal was multi-faceted. First of all, it led to large-scale and even institutionalized corruption, one of the most important reasons that many historians believed caused the decline of Portuguese India. The origin of corruption rooted in the patronage of the Crown in favor of nobility. "All the European nobility of this era habitually believed their king owed them a living and very few of them ever thought they should take the nominal and often minimal salary attached to their posts too seriously." ${ }^{27}$ Through patronage, the Crown and noblemen were strictly linked: the former patronized the latter in order to take advantage of their service, and the latter depended on the former to develop their own career and make money. "As almost everywhere else, the upper echelon of Portuguese society was a network of personal 
relations and of the patrons with their clients formalized by the ceremony of homage and reinforced by favors from the king." ${ }^{28}$ For the Crown of Portugal, the Estado da Índia provided an ideal way to exhibit monarchs' generosity and favor to its subjects.

He (the Crown) concerned himself infinitely less with the peasant digging turnips than with the privileged groups who looked toward him for employment. To employ them was to keep them happy, but to leave them idle was to court the danger that they might drift into someone else's network of interrelationship, may be even someone potentially dangerous. ${ }^{29}$

Thus, the Portuguese India became a deal between these two parts.

In a kingdom where previously the military orders and church had come to monopolize large tracts of lands, capital, and social prestige at home, the Estado had traditionally served as a proving ground and source or reward for a loyal noble class. ${ }^{30}$

The appointment of an official post was based very less on candidates' personal abilities than on lineage, degree of candidates' nobility and private relations. Moreover, an official position was very often given as reward for one's service to the Crown. "M ost of the higher administrative jobs went to members of the court nobility, posts at or above the corregedor, or district governor, level. Probably the lesser officials were a mélange of all aristocratic varieties." ${ }^{\prime 31}$ Plus, Portugal is so small a country that, on one side, people can easily align oneself with others according to birthplace and lineage, and, on the other, the Crown knew very well which one to appoint. Therefore, favoring a bureaucratic 
administration mainly composed of bourgeoisie didn't seem necessary and attractive to the Crown.

With the permissive attitude of the Crown, the nobility's appetite for fortune grew increasingly. According to Franciso Rodrigues de Silveira, a real soldado prático who served in Portuguese India for many years, it was the insatiable greed of the viceroy and his officials and the consequent all-sided corruption that resulted in Portuguese military impotence. Unlike the Spanish administration in America which was basically civilian-oriented, the Portuguese India was military in nature and governed by nobility rather than by clerk. And, because the whole existence of the Estado da Índia depended upon an effective military power, the groundwork of Portuguese India would gradually break down once the military forces were weakened

It might therefore be argued that the decadência was connected with Portugal's failure to replace its warrior class in Asia with a group of men who might better fit the image of bureaucratized pen-pusher. M ore, I suspect, by accident than by deliberation, the conquistadores of Spanish America were nearly all phased out by the 1530's and supplanted with men who soon became accustomed to the ways of formulas, channels, and, if not honest service, at least not collusive dishonesty. M eanwhile, Portugal not only seems to have continued patronizing its conquistador class, but institutionalized and entrenched them in the government of its Indian empire until a more modern bureaucratic evolution was impossible. ${ }^{32}$

According to George Winius, although in the sixteenth-century Portugal the nobility of all varieties numbered only around 20,000, yet they exercised great influence on both the 
king and the country, possibly more than in any other land of Western Europe. The predominance of aristocrats who were pioneers and enthusiasts in the Conquistas gave birth to the prevalence of warrior spirit in Portuguese society where manual work and industry were despised, and vainglory and flaunt cherished. The profits gained from maritime trades were not transformed into productivity but rather were squandered by the Crown and aristocrats to import luxury goods. By importing silk, velvet, brocade and wheat from Italy, glass from Germany, cloth from France and cereal and wool from England, Portugal contributed to the industrialization of her neighbors while impoverishing herself. Portugal became a de facto entrepot transferring wealth from the Orient to other parts of Europe. Although a couple of Portuguese kings and Regent Pedro tried to limit the consumption of luxury goods and to stimulate national manufacturing, Portuguese industrial production was still very inert, because most wealth-holders, especially nobles and men of the cloth, who lacked the mentality of investment and of frugality, would rather buy real estate and treasure than make investment in industry. With such huge sediment of the country's wealth, the Portuguese economy was paralyzed. And, the absolutist regime featuring noble-clerical privilege and landed property was further strengthened at the expense of the povo and the emerging bourgeoisie who were the most suffering victims of "vestigial medieval cycle of economic uncertainty." Without a dynamic domestic economy capable of sustainable development or a process of accumulating, investing and reaccumulating large amounts of capital, the Portuguese seaborne empire shrank dramatically. The most lucrative commerce was monopolized by the Crown and did not serve to foster the growth of a large and productive middle class. 
Profits were absorbed primarily by the court and aristocracy, which occupied the best positions in the thalassocracy, and hence income was drained off by consumption, leaving little to reinvest to meet the mounting costs of warfare, trade, and competition. ${ }^{33}$

Since the very beginning of os Descobrimentos, the supreme merchant had been the State, and the majority of commercial activities were carried out either by officeholders or by the nobility in detriment of small and medium entrepreneurs. Under the oppression of the powerful vested interests, the chance was dim for an autonomous bourgeoisie with its own ideological and political values to develop. While the middle class in other European countries was booming, that in Portugal turned out to be even more underdeveloped after two centuries of maritime expansion, during which the Portuguese social structure experienced no radical modifications. At the outset of os D escobrimentos, Henrique, the Navigator, manifested his objective in a letter to King Duarte: "to save one's soul, to uphold the honor of oneself, one's name lineage and nation, to enjoy the physical pleasure and finally to acquire the worldly gains." ${ }^{34}$ Hundreds of years passed, these goals remained unchanged and the whole Portuguese overseas enterprise kept itself from modern spirits. The structural framework imposed by the internal political, economic and ideological situations of the Portuguese society during $15^{\text {th }}-17^{\text {th }}$ centuries left little chance for bourgeoisie to prosper. The nobles, who took advantage of their administrative posts to occupy the most profitable trades, greatly hindered the growth of the bourgeoisie. Besides, those of the middle class who achieved success were in turn incorporated into the nobility, becoming mercadores-cavaleiros or negociantes-enobrecidos. 
Accordingly, the wealth of Portuguese enterprise in the late fifteenth and sixteenth centuries, in place of nurturing an independent bourgeoisie, enriched and empowered aristocrats and the Crown. As Alexandre Herculano suggested, the longtime Conquistas consumed the dynamic forces of Portugal, which superficially enriched the country but impoverished it in reality. After hundreds of years of conquering the world, Portugal remained as a quasi-medieval society, both in socio-politico-economic structure and in mentality, disengaged from the prospering pre-capitalistic Europe, which I would like to define as "Portuguese anachronism".

The association between the Portuguese Crown, Church, and nobility became inextricably during the maritime expansion, in which the king's resolve, the nobles' valor and the clergy's persistence complemented each other, forming a symbiotic triangle.

[D]ado o catolicismo absoluto, era impossível que se the não seguisse, deduzindo-se dele, o absolutismo monárquico. Dado o absolutismo, vinha necessariamente 0 espírito aristocrático, com o seu cortejo de privilégios [...] os erros políticos e econômicos saíam daqui naturalmente. ${ }^{35}$

Given the predatory and unproductive nature of such alliance and its disastrous impacts on national economy and prowess, the decline of Portuguese empire seemed inevitable. In view of Manuel Bonfin, "um grupo, um organismo social, vivendo parasitariamente sobre outro, há de fatalmente degenerar, decair, degradar-se": However, historians like Glenn Ames and George Souza argued that failures and successes coexisted in Portuguese Asia from the mid $17^{\text {th }}$ century onwards and at times 
the latter could prevail, which accompanied the revival of the House of Braganza. Gentil da Silva also warned us not to understand the Portuguese historical trajectory in unilinear fashion but rather in terms of "oscillations". This kind of oscillations is also mirrored in struggles between the Portuguese bourgeoisie and nobility-clergy, which lasted for centuries. In the light of Jaime Cortesão, until the end of the $15^{\text {th }}$ century, the bourgeoisie played a "motor" role in Portuguese undertakings. But in the next century, the nobility reacted and gained both economic and political upper hand. It was towards the turn of the $16^{\text {th }}$ century that the bourgeoisie, those in provincial seaports in particular, re-acquired their influence. Nevertheless, the final victory went to the noble-cleric alliance which managed to prevail in the last decades of the $17^{\text {th }}$ century and was able to rigidly demarcate the society by debilitating the middle class. In this respect, the evolution of Portuguese empire can be seen as a continuous wave with crests and troughs. Nevertheless, the empire, under the anachronic control of nobility-clergy in prejudice of the bourgeoisie, unavoidably lapsed and relapsed in decline in the course of History.

LIU, Yi. Clergy, Nobility and Crown in Decadência. História, São Paulo, v.24, n.1, p.167-190, 2005.

ABSTRACT: In the current work I intend to inquire into the internal motives that led the Portuguese seaborne empire to decadence. After making a brief review of the historiography about the decline of Estado da India, I proceed to the analysis of the Crown-Church-Nobility triangle in the course of os 
Descobrimentos, and of their respective roles in the evolution of Portuguese empire. The absolutization of the crown, the over-expansion of the clergy and the empowerment of the aristocracy became the most conspicuous and longstanding features in the Portuguese social fabric after the country launched herself into maritime undertakings, which crippled her agriculture and retarded the industrialization. As a consequence, the rise of bourgeoisie and the transformation of mercantilist economy into the capitalist were obstructed, and a strong adventurous but non-productive spirit mixed with disdain of manual work prevailed both in metropolis and in overseas territories. In conclusion, the Portuguese decadence commenced from within rather than from without, and far prior to Dutch intrusions in Portuguese Asia, which only accelerated the decline.

KEYWORDS: Portuguese Empire, Historiography ,mercantilism

\section{NOTES}

1 Department of Portuguese and Brazilian Studies, Brown University, Providence, RI - USA, CEP 02912. Yi_Liu@brown.edu.

${ }^{2}$ AMES, Glenn J. Renascent Empire? The House of Braganza and the Quest for Stability in Portuguese Monsoon Asia, c.1640-1683. Amsterdam: University Press, 2000, p.13

${ }^{3}$ After having seized several Portuguese cities and fortresses in Asia, "the VOC quickly lost its pristine 'entrepreneurial' values, and by the 1660 s was squandering huge amounts of cash to defend and maintain clearly unprofitable holdings like Ceylon. At the same time, the Portuguese learned to adapt to changing technologies, business practices, administrative reforms, and geo-political and religious realities in the Indian Ocean trade.” AMES, Glenn J. op. cit., p.38. 
${ }^{4}$ QUENTAL, Antero de. Causas da Decadência dos Povos Peninsulares nos Últimos Três Séculos, "Prosas Sócio-Políticos". published and presented by Joel Serrão. Lisboa: Imprensa Nacional-Casa de Moeda, 1982 p.279.

${ }^{5}$ SÉRGIO, António. Breve Interpretação da História de Portugal. Livraria Sá da Costa Editora, 1978, p.83

${ }^{6}$ Idem, p. 85

7 BOXER, Charles R. The Portuguese Seaborne Empire 1415-1825. Alfred. A. Knopf ,1969, p.334.

${ }^{8}$ GODINHO, Vitorino Magalhães. A Estrutura na Antiga sociedade Portuguesa. Arcádia, 1971, p.64.

${ }^{9}$ MOOG, Vianna Moog. Bandeirantes e Pioneiros: Paralelo entre Duas Culturas. 19.ed., Graphia, 2000, p.96.

${ }^{10}$ GODINHO, Vitorino Magalhães. Op. cit., p.159.

${ }^{11}$ PAYNE, Stanley G. A History of Spain and Portugal. Library of Iberian Resources Online, Chapter Twelve, p.4. Disponível em: $<<$ libro.uca.edu $>>$.

${ }^{12}$ COATES, Tomothy J. Convicts and Orphans: Forced and State-Sponsored Colonizers in the Portuguese Empire, 1550-1755. Stanford: Stanford University Press, 2001, p.70.

${ }^{13}$ AMES, Glenn J. Op. cit., p.71.

${ }^{14}$ Idem, p.64.

${ }^{15}$ Idem, p.75.

${ }^{16}$ The reign of Regent Pedro coincided with that of the Sun King of France who, although extremely absolutist, was one of the greatest kings in the French history.

${ }^{17}$ AMES, Glenn J. Op. cit., p.228.

${ }^{18}$ PASCOAES, Teixeira de. Arte de Ser Português. Edições Roger Delraux, 1978, p.58.

${ }^{19}$ DIFFIE, Bailey W.; WINIUS, George D. Foundations of The Portuguese Empire 1415-1580. University of Minnesota Press, 1977, p.434.

${ }^{20}$ Idem, p.419.

${ }^{21}$ However, this viewpoint of professor Hamilton has been challenged by a host of scholars in recent years. See Imperial Spain 1469-1716 p.56 by J. H. Elliot.

${ }^{22}$ VEEN, Ernst van. Decay or defeat? an inquiry into the Portuguese decline in Asia, 1580-1645. Universiteit Leiden, 2000, p.21.

${ }^{23}$ Idem, p.433.

24 SARAIVA, José Hermano Saraiva. História de Portugal. 4.ed. Publicação Europa-América, 1993, p.203.

${ }^{25}$ QUENTAL, Antero de. Op. cit., p.284.

26 “Os títulos de fidalgo, cavalheiro ou nobre não são só para se gabar e se ostentar, implicando, ao mesmo tempo, grandes interesses económicos. Tanto 
no reino português como no Brasil colonial, gozaram a camada de nobreza assim como do clero de privilégios como a isenção ou dedução dos impostos cujo grau de dispensa, muitas vezes, varia em conformidade com a posição hierárquica dos envolvidos na pirâmide social e eclesiástica. Assim, se se conseguisse um título mais "decente", se poderia adquirir uma regalia correspondentemente maior. Ademais, a fidalguia, no período colonial, representou um passaporte que possibilitou e facilitou o acesso às entidades administrativas e instituições políticas. Como todos sabem, os desígnio políticos, afinal, servem para os interesses económicos e não é muito difícil de imaginar que num sistema político colonial muito corrupto, como o caso do Brasil, fosse muitíssimo elevada a recompensa econômica para os esforços empreendidos para se obter uma posse administrativa (por exemplo, vereador). Portanto, a procura ansiosa pelos títulos e famas não auferiu unicamente da paixão pela glória e vanglória, mas faz parte da busca de ganho substancial também." LIU Yi. Homem Cordial da Casa e Homem Mascarado da Rua, p.4, unpublished.

${ }^{27}$ DIFFIE, Bailey W.; WINIUS, George D. Op. cit., p.419. Many historians have argued that the officeholders depended much more on the "redistributive system" than on salaries. "In his study of The Structural Crisis of European-Asian Trade in The Early Seventeenth Century, Niels Steensgaard argues that the Portuguese were concerned less with monopolizing commerce than with controlling and preying upon it, that their officials were remunerated more by a share of prey than by salaries, and that to eliminate corruption was therefore impossible without paradoxically eliminating the Estado da Índia itself." DISNEY, A. R. Op. cit., p.58

${ }^{28}$ VEEN, Ernst van. Op. cit., p19.

${ }^{29}$ WINIUS, George D. The Portuguese Asian "Decadência" Revisted, "Empire in Transition: The Portuguese World in the Time of Camões". Ed. Alfred Hower and Richard A. Preto-Rodas, University of Florida Press, 1985, p.75.

${ }^{30}$ AMES, Glenn J. Op. cit., p.211.

${ }^{31}$ DIFFIE, Bailey W.; WINIUS, George D. Op. cit., p.421.

${ }^{32}$ WINIUS, George Davison. Op. cit., p.77.

${ }^{33}$ PAYNE, Stanley G. Op. cit., p.7.

${ }^{34}$ VEEN, Ernst van. Op. cit., p. 18

${ }^{35}$ QUINTAL, Antero de. Op. cit., p.292-3.

${ }^{35}$ BONFIM, Manuel. A América Latina. In: SANTIAGO, Silviano. Intérpretes do Brasil, v.I. Nova Aguilar, 2002, p.651. According to Bonfim, the reason why the decline of parasites is fatal is that they are isolated from the Nature and make no efforts to know the world and phenomena since their needs are already satisfied.

Artigo recebido em 04/2006. Aprovado em 06/2006. 